Synthesis of Natural

Products and

Potential Drugs

\section{Synthesis of TP-2758}<smiles>COc1cc(C=O)c(OC)c(C)c1OC</smiles>

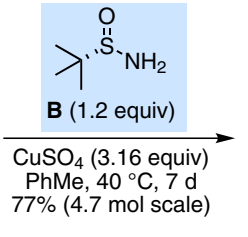
A<smiles>COc1c(/C=N/[13CH]=[V])cc([N+](=O)[O-])c([O-])c1C</smiles>
mp not reported OMe

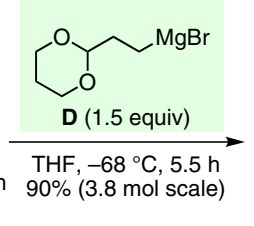<smiles>CC(C)(C)S(=O)(=O)c1ccc(F)cc1</smiles>
reported<smiles>CC1OCCCO1</smiles>
1. TFA- $\mathrm{H}_{2} \mathrm{O}(1: 1), 6^{\circ} \mathrm{C}$ $\mathrm{NaBH}(\mathrm{OAC})_{3},-20^{\circ} \mathrm{C} \quad 1.8 \mathrm{~mol}$ scale

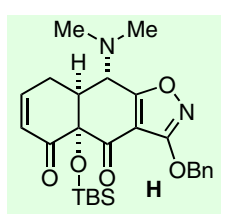

$$
\begin{gathered}
\text { G }(1.1 \text { equiv) } \\
\text { LDA (1.2 equiv) } \\
\text { TMEDA (1.3 equiv) } \\
\text { THF, }-78^{\circ} \mathrm{C} ; \\
\hline \text { add } \mathbf{H}(1.0 \text { equiv }) \\
-78^{\circ} \mathrm{C}, 50 \text { min; } \\
\text { add LHMDS (1.1 equiv) } \\
-78 \text { to }-10^{\circ} \mathrm{C} \text {. } \\
89 \%(600 \text { mmol scale })
\end{gathered}
$$<smiles>CCN1CCCC1c1cc(OC)c(C(=O)Oc2ccccc2)c(C)c1OC</smiles>
$\mathrm{MeCHO}(1.2$ equiv)
$\mathrm{NaBH}(\mathrm{OAC})_{3}(3.0$ equiv)
$\mathrm{AcOH}(5.8$ equiv)
$\mathrm{MeOH},-20^{\circ} \mathrm{C}, 20 \mathrm{~min}$
$90 \%$ from L<smiles>COc1cc([C@H]2CCCN2)c(OC)c(C)c1C(=O)Oc1ccccc1</smiles>
not reported
$98.7 \%$ ee

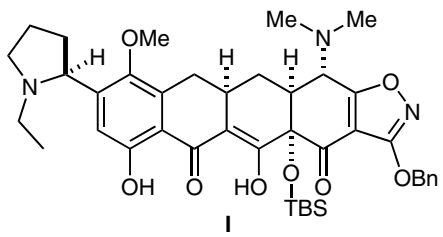

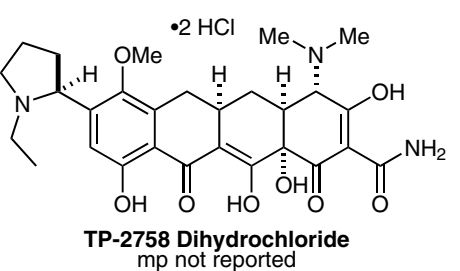

Key words

TP-2758

asymmetric deprotonation

Ellman-Davis synthesis

Negishi reaction

palladium catalysis

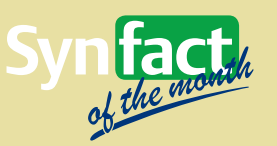
asymmetric amine

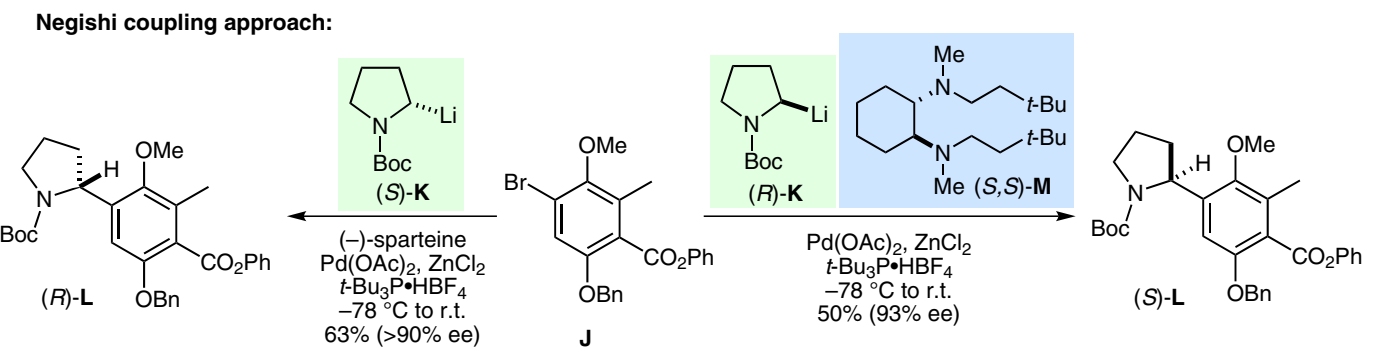

Significance: TP-2758 is in development for the treatment of complicated urinary tract infections caused by Gram-negative pathogens. The closing stage of the synthesis depicted features the installation of the chiral pyrrolidine moiety in fragment $\mathbf{G}$ using Ellman's chiral sulfinamine auxiliary B (99\% ee). The conjunction of complex fragments $\mathbf{G}$ and H using chemistry developed by Myers and coworkers (J. Am. Chem. Soc. 2008, 130, 17913) delivered the advanced intermediate $\mathbf{I}$ in $89 \%$ yield.
Comment: Enantioselective deprotonation of $N$-Boc pyrrolidine using s-BuLi and (-)-sparteine afforded the lithium reagent (S)-K that participated in a palladium-catalyzed Negishi coupling with bromoarene $\mathbf{J}$ to give enantioenriched pyrrolidine $(R)$ - $\mathbf{L}$ in $63 \%$ yield (>90\% ee). By using diamine $(S, S)$-M as a (+)-sparteine surrogate, the corresponding Negishi reaction delivered (S)-L in 50\% yield (93\% ee). Neither of these alternatives was robust, and the yields could not be improved.

SYNFACTS Contributors: Philip Kocienski

Synfacts 2016, 12(5), 0439 Published online: 18.04.2016

Dol: 10.1055/s-0035-1561984; Reg-No.: K02016SF 